\title{
Peranan Partai Politik dalam Melaksanakan Pendidikan Politik
}

\section{The Role of Political Parties In Conducting Political Education}

\author{
Payerli Pasaribu * \\ Program Studi Pendidikan Antropologi, Fakultas Ilmu Sosial, \\ Universitas Negeri Medan, Indonesia
}

\begin{abstract}
Abstrak
Partai politik adalah kelompok yang terorganisasi dan anggotanya mempunyai orientasi, nilai-nilai dari cita-cita yang sama. Tujuannya untuk memperoleh kekuasaan politik dan memperebut kedudukan politik, biasanya dengan cara konstitusional untuk melaksanakan kebijaksanaan-kebijaksanaan mereka. Dengan demikian dapat dikatakan bahwa partai politik merupakan salah satu intruksi inti dan demokrasi modern. Demokrasi modern mengandalkan sebuah sistem yang disebut keterwakilan (repressentif), baik keterwakilan lembaga formal kenegaraan seperti parlemen (DPRD/DPR) maupun keterwakilan aspirasi masyarakat dalam instruksi kepartaian. Partai politik berfungsi untuk mencari dan mengajar orang yang berbakat untuk turut aktif dalam kegiatan politik sebagai angota partai dengan demikian turut berpartisipasi politik. Inilah yang menjadi peran penting dalam partai politik untuk memberi pendidikan politik bagi masyarakat.

Kata Kunci: Peranan; Partai Politik; Pendidikan Politik.
\end{abstract}

\begin{abstract}
Political parties are organized groups and their members have an orientation, values of the same ideals. The aim is to gain political power and to seize political positions, usually by constitutional means to implement their policies. Thus it can be said that political parties are one of the core instructions and modern democracy. Modern democracy relies on a system called representation (repressentif), whether the representation of formal state institutions such as parliament (DPRD / DPR) and representation of community aspirations in party instructions. Political parties function to seek and teach talented persons to actively participate in political activities as party members thus participate in politics. This is an important role in political parties to provide political education for the community.
\end{abstract}

Keywords: Roles; Political parties; Political Education.

How to Cite: Pasaribu, P., (2017). Peranan Partai Politik dalam Melaksanakan Pendidikan Politik. JPPUMA: Jurnal Ilmu Pemerintahan dan Sosial Politik, 5 (1): 51-59

\begin{tabular}{lr}
\hline${ }^{*}$ Corresponding author: & p-ISSN: 2549 1660 \\
E-mail: armansyah@staff.uma.ac.id & e-ISSN: 2550-1305
\end{tabular}


Payerli Pasaribu, Peranan Partai Politik dalam Melaksanakan Pendidikan Politik.

\section{PENDAHULUAN}

Kekuatan sejati negara demokrasi tidak terletak pada negara atau pemerintahannya, akan tetapi pada warga negaranya. Di negara demokrasi rakyat biasa bebas memenuhi segenap kebutudan teknologihannya, bebas memperbaiki nasib sendiri, dan bebas berkembang sesuai dengan kemungkinan-kemungkinan yang ada pada dirinya. Maka tugas pokok negara demokrasi ialah mengembangkan segenap potensi yang terdapat pada rakyatnya di tengah iklim yang damai dan adil.

Untuk pelaksanaan demokrasi paling tidak diperlukan peranan politik membentuk sikap demokrasi kalangan warga negara agar tercapai suatu kreativitas warga sebagai basis sumber daya politik, pemindahan atau pengoperan nilai-nilai hukum dan nilai-nilai moral. Warisan benda-benda budaya, keyakinan agama yang dianut, pengetahuan dan teknologi dan lain-lain. Tingginya tingkat pendidikan dan kebudayaan rakyat akan menjadi suatu barometer bagi pertumbuhan bangsa dan negara yang bersangkutan khusus Negara Indonesia. Sebab itulah negara, khususnya negara demokrasi, sangat berkempentingan dengan pendidikan seluruh warga negaranya demi menanamkan normanorma demokrasi dan ikut bertanggung jawab atas diterapkannya asas demokrasi.

Bagi negara-negara yang merdeka dan berdaulat, eksistensi partai politik merupakan prasyarat, negara melalui wakil-wakilnya yang duduk dalam badanbadan perwakilan rakyat.Pada dasarnya pembentukan, pemeliharaan dan pengembangan partai politik merupakan salah satu penerimaan hak warga negara untuk berkumpul, berserikat dan menyatakan pendapat. Melalui partai politik, rakyat dapat mewujudkan haknya untuk mengatakan pendapat tentang arah kehidupan dan masa depannya dalam bermasyarakat dan bernegara. Partai politik merupakan komponen yang sangat penting dalam sistem politik demokrasi. Dengan demikian, penataan kepartaian harus bertumpu pada kaidah-kaidah kedaulatan rakyat, yaitu memberikan kebebasan, kesetaraan dan kebersamaan.

Melalui kebebasan yang bertanggung jawab segenap warga nergara memiliki hak untuk berkumpul dan berserikat guna mewujudkan cita-cita politiknya secara nyata. Kesetaraan merupakan prinsip yang memungkinkan segenap warga negara berpikir dalam kerangka kesederajatan sekalipun kedudukan, fungsi dan peran masing-masing berbeda. Kebersamaan adalah wahana untuk mencapai tujuan berbangsa dan bernegara sehingga segala bentuk tantangan lebih mudah dihadapi. Partai politik dapat mengambil peranan penting dalam menumbuhkan kebebasan, kesetaraan, dan kebersamaan sebagai upaya untuk membentuk bangsa dan negara yang terpadu.

Dalam sistem politik demokrasi, kebebasan dan kesetaraan tersebut dapat diimplementasikan agar dapat merefleksikan rasa kebersamaan yang menjamin terwujudnya cita-cita kemasyarakatan secara utuh. Disadari bahwa proses menuju kehidupan politik yang memberikan peran kepada partai politik sebagai asset nasional berlangsung berdasarkan prinsip perubahan dan kesinambungan yang makin lama makin menumbuhkan kedewasaan dan tanggungjawab berdemokrasi. Hal ini dapat dicapai melalui penataan kehidupan kepartaian, disamping adahnya sistem dan proses pelaksanaan pemilihan umum secara memadai.

Dalam negara demokrasi modern, partai politik sering dianggap sebagai salah satu atribut negara, karena tidak ada seorang ahlipun yang dapat menolak ekistensinya, karena partai politik sangat diperlukan kehadirannya bagi negara merdeka dan berdaulat. Kesemua fungsi ini diwujudkan melalui pemilihan umum yang diselenggarakan secara demokrasi, jujur dan adil dengan mengadakan pemberian dan pemungutan suara secara langsung, umum, bebas, dan rahasia.

Partai politik merupakan salah satu institusi inti dan demokrasi modern. 
Demokrasi modern mengadaikan sebuah sistem yang disebut keterwakilan, baik keterwakilan lembaga formal kenegaraan seperti (DPR, DPRD) maupun keterwakilan aspirasi masyarakat dalam institusi kepartaian.

Partai politik seharusnya melaksanakan fungsinya dengan baik sehingga dapat menjadikan suatu negara yang demokratis, tetapi pada kenyataannya tidak semua fungsi tersebut telah dilaksanakan oleh partai-partai politik yang ada. Meingat fungsi partai politik yang begitu penting, sering bahkan keberadaan dan kinerjanya merupakan ukuran mutlak bagaimana demokrasi berkembang disuatu Negara. Meskipun ia bukan merupakan pelaksana dan suatu pemerintahan, namun keberadaannya akan mempengaruhi bagaimana dan arah mana pelaksanaan pemerintahan dijalankan.

Pendidikan politik yang dilaksanakan partai politik antara lain ialah berpartisipasi secara aktif dan kreatif dalam kehidupan berbangsa dan bernegara, sadar akan hak dan kewajiban suatu tanggung jawabnya sebagai warga Negara terhadap kepentingan bangsa dan negara. Dengan demikian pendidikan politik akan menjadi sarana, terpeliharanya stabilitas nasional guna memperlancar usaha pencapaian cita-cita bangsa melalui pembangunan.

\section{PEMBAHASAN}

Dalam Kamus Besar Bahasa Indonesia (2001:667), dinyatakan bahwa peranan berasal dari kata "Peran" yang berarti sebagai seperangkat tingkat yang diharapkan dimiliki oleh seseorang yang berkedudukan di masyarakat, kemudian peranan adalah bagian dari tugas utama yang harus dilaksanakan. Peranan merupakan bagian dari sesuatu yang harus dilaksanakan berdasarkan ketepatan waktu, dalam hal yang menjadi bagian dari apa yang dilakukan dalam hal pemegang pimpinan.
Selanjutnya menurut Darminto (200: 735), Peranan diartikan sebagai sesuatu yang menjadi bagian atau yang memegang pimpinan yang terutama dalam terjadinya suatu hal atau peristiwa. Maka, dapat diketahui bahwa peranan adalah kemampuan yang dimiliki seseorang untuk mengendalikan sesuatu dalam kehidupan bernasyarakat untuk dapat hidup secara layak demi kehidupan yang sedang dijalankannya.

Secara umum dapat dikatakan bahwa partai politik adalah suatu kelompok yang terorganisir yang anggotaanggotanya mempunyai orientasi, nilainilai dan cita-cita yang sama. Tujuan kelompok ini ialah untuk memperoleh kekuasaan politik dan merebut kedudukan politik (biasahnya) dengan cara konstitusional untuk melaksanakan kebijaksanaan-kebijaksanaan mereka. Hal ini sesuai dengan apa yang dikatakan oleh Budiardjo (2000: 161) bahwa: Partai Politik adalah sekelompok manusia yang terorganisir secara stabil dengan tujuan merebut atau mempertahankan penguasaan terhadap pemerintahan bagi pimpinan partainya dan berdasarkan penguasaan ini memberikan anggota partainya kemanfaatan yang bersifat idiil maupun materil. Partai politik adalah sekelompok manusia yang terorganisasikan sebagai suatu kesatuan politik, dan meanfaatkan kekuasaannya untuk kebijakan umum yang mereka buat. Menurut Badudu (2001: 100) bahwa: "Partai berasal dari dan kata "part" yang berarti "bagian" dan menunjukkan kepada bagian dari para warga Negara. Sedang kata "partai" menunjukkan kepada sekumpulan orang-orang. Jadi menunjukkan kepada sekumpulan sejumlah warga dan suatu negara yang menggabungkan suatu kesatuan yang mempunyai tujuan tertentu"

Soltan Budiardjo (2006: 162) juga mengatakan bahwa:

"Partai politik adalah sekelompok warga negara yang sedikit banyaknya 
terorganisir, yang bertindak sebagai suatu kesatuan politik dan yang dengan memanfaatkan kekuasaannya untuk memilih, bertujuan menguasai pemerintahan dan melaksanakan kebijaksanaan umum mereka".

Dengan demikian dapat dikatakan bahwa partai politik merupakan salah satu institusi inti dan demokrasi modern. Demokrasi modern mengandalkan sebuah sistem yang disebut keterwakilan (repressentif), baik keterwakilan lembaga formal kenegaraan seperti parlemen (DPR/DPRD) maupun keterwakilan aspirasi masyarakat dalam institusi kepartaian.

Neuman dalam karangannya Modern Political Parties, dalam buku Budiardjo (2000: 163) juga mengatakan bahwa: Partai politik adalah organisasi dari aktivitasaktivitas politik yang berusaha untuk menguasai kekuasaan pemerintahan serta merebut dukungan rakyat atas persaingan dengan suatu golongan atau golongan yang mempunyai pandangan yang berbeda.

Partai politik adalah organisasi oleh sekelompok manusia yang melakukan kegiatan-kegiatan politik dalam hal menjalankannya aktivitas politiknya sebagai pelaku maupun anggota politik demi mencapai cita-cita yang diharapkan atas dasar persamaan kehendak. Dalam Undang-Undang Republik Indonesia Nomor 31 Tahun 2008 tentang Partai Politik menyatakan bahwa yang dimaksud dengan partai politik adalah "Organisasi social yang dibentuk oleh sekelompok warga negara Republik Indonesia secara sukarela atas dasar persamaan kehendak dan cita-cita untuk memperjuangkan kepentingan anggota, masyarakat, bangsa dan negara melalui pemilihan umum".

Kegiatan seseorang dalam partai politik merupakan suatu bentuk partisipasi politik mencakup semua kegiatan sukarela melalui mana seseorang turut serta dalam proses pemilihanpemilihan politik dan turut serta secara langsung ataupun dengan wakil-wakil rakyat yang duduk dalam badan itu, berkampanye dan menghadiri kelompok diskusi dan sebagainya. Kebalikan dari partisipasi politik adalah "apatis". Seseorang dinamakan apatis (secara politik) jika dia tidak ikut serta dalam kegiatan-kegiatan tersebut di atas.

Peranan masyarakat sangat penting untuk perbaikan mekanisme penyelenggaraan negara. Persaingan untuk memenangkan kekuasaan, yang dilandasi dengan perebutan posisi jabatan publik merupakan hal yang penting dalam partai politik. Dengan demikian dapat diketahui bahwa partai politik adalah suatu kelompok yang terorganisir yang anggotaanggotanya mempunyai orientasi, nilainilai dan cita-cita yang sama dengan memanfaatkan kekuasaannya untuk memilih, menguasai pemerintahan dan melaksanakan kebijaksanaan menurut peraturan yang dianut.

Partai-partai politik yang terorganisir timbul pada akhir abad ke-18 dan 19 di Eropa Barat, sebagai buah dan usahausaha kelompok-kelompok di luar lingkungan kekuasaan politik untuk bersaing memperebutkan jabatan pemerintahan dan mengendalikan kebijaksanaan pemerintahan. Ketika gerakan-gerakan kelas mengendalikan dan kelas buruh ini mulai mendesak kelaskelas atas dan aristoktrat demi partisipasi dalam pembuatan keputusan, kelompokkelompok yang menjalankan pemerintahan terpaksa mencari dukungan publik dalam rangka mempertahankan pengaruh dominan mereka. Dengan demikian partai-partai politik itu merupakan penghubung antara rakyat dengan pemerintahan dan di dunia modern. Sifat-sifat dan sistem kepartaian suatu negara menentukan sifat dan hubungan ini.

Dalam Undang-Undang Dasar Negara Kesatuan Republik Indonesia Tahun 1945 memang tidak dijumpai kata atau kalimat yang menyebutkan partai politik, hal ini bukan berarti bahwa partai politik tidak boleh diatur, apalagi kalau menyangkut kepentingan bangsa dan 
negara, akan tetapi pembentukan partai politik pada dasarnya merupakan salah satu pencerminan hak warga negara untuk berserikat, berkumpul dan menyatakan pendapat. Hal ini sesuai dengan isi pasal 28 UUD 1945 yang mengatakan "Kemerdekaan berserikat dan berkumpul, mengeluarkan pikiran dengan lisan dan tulisan dan sebagainya ditetapkan dengan Undang-Undang.

Kehadiran organisasi/partai di Indonesia dimulai dengan munculnya organisasi politik seperti Golkar, PDI, Demokrat, PKS dan kelompok-kelompok yang berdasarkan suku kedaerahan seperti panguyuban pasundan dan lain sebagainya yang hingga sampai pada saat ini masih banyak lagi partai-partai politik yang berlatar belakang sesuai dengan keinginan dan paham pembuat/pelopor partai politik tersebut.

Dalam sistem politik, partai politik adalah bagian dan infrastruktur politik yang menampung dan menyalurkan aspirasi masyarakat, baik berupa dukungan, keluhan ataupun tuntutan. Infrastruktur politik adalah kehidupan politik yang berlangsung melalui organisasi social politik (Miriam Budiardjo, 2002: 405).

Secara mendasar, partai politik di negara demokratis dan negara otoriter berbeda. Perbedaan pandangan tersebut berimplikasi pada pelaksanaan tugas atau fungsi partai masing-masing Negara. Di negara demokrasi partai relatif dapat menjalankan fungsi sesuai hakikatnya pada saat kelahirannya, yakni menjadi wahana bagi warga negara untuk berpartisipasi dalam pengelolaan kehidupan bernegara dan memperjuangkan kepentingannya dihadapan penguasaan. bahwa:

Sukarna (2003: 79) menyatakan

"Dalam setiap negara demokrasi terdapatnya partai politik lebih dan sama merupakan syarat yang paling menonjol, meingat rakyat mempunyai alternatif untuk memilih. Tanpa adanya pilihan alternatif maka rakyat akan sukar untuk mengeluarkan aspirasiaspirasinya yang paling cocok dengan dirinya. Oleh karena itu, adanya wadah penyaluran pemikiran yang berbeda-beda merupakan suatu conditiosince quanon atau suatu kondisi yang mau tidak mau harus ada. Tanpa adanya partai politik yang lebih dari satu. Maka demokrasi dapat ditegakkan.

Dengan demikian untuk melihat itu demokrasi atau tidak salah satu aspeknya adalah dilihat dari kehidupan politik. Jika kehidupan partai politik dapat tumbuh dengan subur dan rakyat menentukan pilihannya secara bebas dan rahasia, maka menandakan bahwa negara tersebut minimal mempunyai persyaratan untuk tegaknya demokrasi.

Menurut Budiardjo (2000: 166-168) partai politik menyelenggarakan beberapa fungsi yaitu:

1) Partai sebagai sarana komunikasi politik.

Salah satu tugas dari partai politik adalah menyalurkan aneka ragam pendapat dan aspirasi masyarakat dan mengatur sedemikian rupa sehingga kesimpangsiuran pendapat dalam masyarakat berkurang. Dalam masyarakat modern yang begitu luas pendapat dan aspirasi seseorang tersebut atau suatu kelompok akan hilang tak berbekas seperti suara di padang pasir. Apabila tidak ditampung dan digabungkan dengan pendapat dan aspirasi orang lain yang senada. Proses ini dinamakan penggabungan kepentingan ("interest aggregation"). Sesudah digabung pendapat dan aspirasi ini diolah dan dirumuskan "Perumusan Kepentingan" (interest articulation).

2) Partai Politik sebagai sarana sosialisasi politik

Partai politik juga main peranan sebagai sarana sosialisasi politik (instrument of political sosioauisation). Di dalam ilmu politik, sosialisasi politik diartikan sebagai proses melalui mana seseorang memperoleh sikap dan orientasi 
Payerli Pasaribu, Peranan Partai Politik dalam Melaksanakan Pendidikan Politik.

terhadap fenomena politik, yang umumnya berlaku dalam masyarakat dimana ia berada. Biasanya proses sosialisasi berjalan secara berangsurangsur dari masa kanak-kanak sampai dewasa. Proses sosialisasi politik diselenggrakan melalui ceramah-ceramah penerangan, kursus kader, kursus penataran dan sebagainya.

Partai politik juga berfungsi untuk mencari dan mengajak orang yang berbakat untuk turun aktif dalam kegiatan politik sebagai anggota partai (political recruitmen) dengan demikian partai politik turut memperluaskan partisipasi politik. Caranya ialah melalui kontak pribadi, persuasi dan lain-lain. Juga diusahakan untuk menarik golongan muda untuk dididik menjadi kadernya yang di masa mendatang akan mengganti pimpinan lama (selection of leadership).

4) Partai Politik sebagai sarana pengatur konflik (conflict manajement)

Dalam suasana demokrasi, persaingan dan perbedaan pendapat dalam masyarakat merupakan soal yang wajar. Jika sampai terjadi konflik, pasti politik berusaha untuk mengatasinya".

Pendidikan politik, menurut Sukarna (1994: 84) bahwa:

"Pendidikan politik (political education) merupakan condition quo non (suatu syarat mutlak) mengingat dalam pendidikan politik mendidik kesadaran bernegara dan berbangsa. Partai politik di negara yang belum merdeka sangat mengutamakan pendidikan politik ini sehingga anggota-anggota partai politik punya kader yang tinggi untuk mewujudkan negara merdeka. Dalam negara yang sudah merdeka, pendidikan politik harus tetap dilakukan agar kemerdekaan bangsa dan negara tidak hilang atau dijajah kembali dalam bentuk penjajahan yang lebih halus."

Dengan demikian dapat diketahui bahwa partai politik memiliki beberapa fungsi, yang diantaranya adalah partai politik sebagai pendidikan politik, rekrutmen politik dan sarana pengatur konflik. Dalam hal ini penulis hanya meneliti fungsi partai politik sebagai pendidikan politik, sehingga kelak dapat diketahui apakah partai politik telah menjalankan salah satu fungsinya pada suatu wilayah yakni sebagai sarana pendidikan politik kepada masyarakat.

Alfian (dalam Kartono, 2000: 97) menjelaskan:

"Pendidikan politik (dalam arti yang lebih ketat) dapat diartikan sebagai usaha yang sadar untuk mengubah proses pendidikan politik masyarakat sehingga mereka memahami dan menghayati betulbetul nilai-nilai yang terkandung dalam suatu sistem politik yang ideal yang hendak dibangun. Hasil penghayatan ini akan melahirkan sikap dan tingkah laku politik baru yang mendukung sistem politik yang ideal itu bersamaan dengan itu lahir pulalah kebudayaan baru."

Dengan demikian pendidikan politik masyarakat adalah merupakan rangkaian usaha untuk mewujudkan masyarakat adil dan makmur berdasarkan pancasila, selama ini mengalami gelombang pasang surut yang luar biasa. Pendidikan politik juga merupakan bagian proses pembaharuan kehidupan politik bangsa Indonesia yang sedang dilakukan dewasa ini dalam rangka menciptakan suatu sistem politik yang benar-benar demokratis, dinamis dan efisien.

Kansil (2000 : 197) mengatakan bahwa: Tujuan pendidikan politik ialah menciptakan generasi muda Indonesia yang sadar akan kehidupan berbangsa dan bernegara berdasarkan Pancasila dan UUD 1945 sebagai salah satu usaha untuk membangun manusia Indonesia seutuhnya yang perwujudannya akan terlihat dalam perilaku hidup bermasyarakat.

Pendidikan politik adalah upaya yang dilakukan oleh masyarakat dalam mencapai pembaharuan kehidupan politik dalam sehari-harinya, demi tercipta 
masyarakat yang sejahtera yang dapat diterima baik secara formal maupun non formal.

Poerwanto (2003: 243), "Pendidikan politik dapat ditempuh melalui 2 (dua) cara yakni, secara formal dan non formal maksudnya ialah cara pendidikan yang diterima baik di lingkungan keluarga dan masyarakat luas."

Menurut Djiwandono dalam Sumantri (2003: 23) bahwa: "Pendidikan politik merupakan suatu proses penyampaian budaya politik bangsa yang mencakup cita-cita politik dan normanorma operasional dan sistem organisasi politik yang berdasarkan nilai-nilai pancasila penting bagi seluruh rakyat, seluruh warga.

Pendidikan politik adalah suatu upaya yang dilakukan seseorang maupun lebih yang mana dilakukannya dengan sadar dalam proses penyampaian budaya politik bangsa dengan memperhatikan nilai-nilai Pancasila. Berdasarkan hal tersebut, pendidikan politik merupakan usaha untuk mengarahkan proses pendidikan politik masyarakat pada tatanan sistem politik yang ideal. Bagi masyarakat Indonesia yang majemuk, sistem politik yang diinginkan adalah Demokrasi Pancasila.

Oleh karena itu, kesadaran politik merupakan kesadaran yang harus dimiliki oleh setiap warga negara. Kesadaran politik merupakan kondisi psikologis yang tanggap terhadap suatu hal tentang negara. Ramlan Surbakti (dalam Kharim, 2004: 109) mengemukakan bahwa politik adalah "hak dan kewajiban sebagai warga negara menyangkut minat dan perhatian seseorang terhadap lingkungan masyarakat dan politik".

Menurut Pasal 31 Undang-Undang No.2 Tahun 2008, tujuan pendidikan politik antara lain: 1) Meningkatkan kesadaran hak dan kewajiban masyarakat dalam kehidupan bermasyarakat, berbangsa dan bernegara. 2) Meningkatkan partisipasi politik dan inisiatif masyarakat dalam kehidupan bermasyarakat, berbangsa dan bernegara.
3) Meningkatkan kemandirian, kedewasaan, dan membangun karakter bangsa dalam rangka memelihara persatuan dan kesatuan bangsa.

Pendapat tersebut menjelaskan bahwa pendidikan politik, dapat dibentuk insane-insan yang memiliki politik, artinya insane yang mamapu menerima informasi mengenai proses penyelenggaraan negara, pembuatan keputusan, serta memahami keterampilan politik dalam menumbuhkan nilai moral yang fundamental dalam berdemokrasi.

Penyelenggaraan pendidikan politik harus dapat meningkatkan kesadaran kehidupan berbangsa dan bernegara, kemampuan bangsa, pengembangan pribadi itu, pendidikan politik harus mampu membangkitkan kesadaran rakyat untuk mengenal permasalahan politik yang belum terpecahkan. Bentuk pendidikan politik yang dilaksanakan oleh partai politik pada umumnya berupa kegiatan kampanye dan kaderisasi

Dalam kegiatan kampanye ini, biasahnya suatu partai berusaha mengumpulkan massa sebanyakbanyaknya pada suatu tempat. Setelah massa berkumpul maka orang-orang yang memang aktif dalam partai akan menjalankan misinya yang bertujuan untuk menarik simpati massa. Dalam kegiatan ini, biasanya orang-orang yang mempunyai kedudukan penting dalam suatu partai politik memaparkan programprogram yang akan dijalankan oleh partai politik tersebut, apabila menang dalam pemilihan umum. Dalam hal ini, partai politik berusaha dengan semaksimal mungkin untuk mempengaruhi massa yang ada.

Kampanye yang dilaksanakan oleh partai-partai politik ini biasanya diselenggarakan pada saat-saat akan diselenggarakan pemilihan umum. Kampanye ini biasahnya dilaksanakan oleh partai politik yang bersangkutan pada anggota masyarakat.

Kaderisasi berbeda dengan kampanye, karena dalam kaderisasi di ikuti oleh orang-orang yang memang 
Payerli Pasaribu, Peranan Partai Politik dalam Melaksanakan Pendidikan Politik.

sudah menjadi anggota dan suatu partai politik. Kaderisasi diorganisasi manapun merupakan urat nadi dan sebuah organisasi. Kaderisasi adalah proses penyiapan SDM agar kelak mereka menjadi pemimpin yang mampu membangun peranan dan fungsi organisasi secara lebih bagus.

Ada dua persoalan yang penting, pertama, bagaimana usaha-usaha yang dilakukan oleh organisasi untuk meningkatkan kemampuan baik pengetahuan maupun keterampilan. Kedua, adalah kemampuan untuk menyediakan stok kader atau SDM organisasi, dan terutama di khususkan pada kaum muda. Ini merupakan bentuk pendidikan politik dimana selama ini peran tersebut terabaikan. (Koirudin, 2004: 113).

Tujuan diadakannya kaderisasi ini adalah agar semua anggota partai politik dapat menjalankan fungsinya di dalam badan negara. Karena kader-kader partai inilah yang nantinya akan menjalankan tugas-tugas badan negara. Jadi, kalau kader tidak mempunyai wawasan yang luas dalam Ilmu Politik, Ekonomi, Sosial Budaya, Pertahanan Keamanan Nasional, maka partai politik ini akan gagal mengedalikan negara. Karena itu, partai harus mempunyai kader-kader intelektual yang mempunyai wawasan pemikiran yang cukup luas baik Nasional maupun Internasional. Dalam kaderisasi ini, partai politik berusaha menanamkan nilai-nilai dasar, tujuan, program partai yang bersangkutan, disamping ilmu-ilmu yang menunjang terhadap kekuatan partai.

\section{SIMPULAN}

Peranan partai politik menyalurkan pendapat aspirasi masyarakat dalam mengatur sedemikian rupa sehingga simpang siur pendapat dalam masyarakat berkurang. Partai politik juga berfungsi untuk mencari dan mengajar orang yang berbakat untuk turut aktif dalam kegiatan politik sebagai angota partai dengan demikian turut berpartisipasi politik.
Partai politik memiliki suatu peranan penting dalam membentuk setiap partai yang di jalankan setiap anggotaanggotanya. Sebaiknya Partai Politik lebih memperhatikan akan hal-hal apa-apa saja yang perlu dipenuhi dalam hal kepartaian serta melaksanakan tugasnya sebagai anggota partai politik dengan baik, apabila sudah duduk di salah satu kursi dewan. Partai politik lebih lagi meningkatkan kualitas keanggotaannya, baik dalam kedisiplinan maupun lain sebagainnya, ini akan mempermudah dalam mencapai tujuan bersama. Meningkatkan kualitas keanggotaan tidak la hanya berpatokan pada kaderisasi, namun harus melihat apa yang harus dicapai pada tujuan bersama, jangan hanya mementingkan kepentingan keanggotaan, namun mencapai tujuan bersama.

\section{DAFTAR PUSTAKA}

Alfian, (2002). Pemikiran dan Perubahan Politik Indonesia, Jakarta: Pustaka Utama.

Arikunto, (2001). Prosedur Penelitian, PT. Rineka Cipta Jakarta.

Badudu, J.S., (2001). Kamus Besar Bahasa Indonesia, Cetakan ke-1, Jakarta: Pustaka Sinar Harapan.

Budiarjo, M., (200o). Dasar-Dasar Ilmu Politik, Jakarta: Pustaka Utama. ., (2002). Dasar-Dasar Ilmu Politik, Cetakan IV, Jakarta: Pustaka Utama.

Departemen Pendidikan dan Kebudayaan, (2001). Kamus Besar Bahasa Indonesia, Jakarta: Balai Pustaka.

Kadir, A., (2013). Peranan Partai Politik dalam Menanggulangi Golongan Putih (Golput) pada Pemilihan Legislatif 2009, Jurnal Ilmu Pemerintahan dan Sosial Politik, 1 (1): 65-75.

Kansil, (2001). Peran Partai Politik, Bandung: Tarsito.

Khoiruddin, (2004). Partai Politik dan Agenda Transmisi Demokrasi, Yogyakarta: Pustaka Utama.

Kusmanto, H, (2014). Partisipasi Masyarakat dalam Demokasi Politik, Jurnal Ilmu Pemerintahan dan Sosial Politik, 2 (1): 78-90 
Panitia Pemilihan Indonesia, (2001). Indonesia Memilih: Pemilihan Umum di Indonesia yang Pertama, Jakarta.

Poewanto, P.P, (2004). Partai Politik di Indonesia, Jakarta: PT. Rineka Cipta

Rahmadani, A., Irwan N., dan Husni T.N., (2013), Pengaruh Pendidikan dan Latihan (Diklat) Sebagai Upaya Peningkatan Kerja Pada Polda Sumatera Utara, Jurnal Ilmu Administrasi Publik Universitas Medan Area, 1 (1): 1-5

Ramlan, S., (2004), Sistem Politik Indonesia, Yogyakarta: Graha Ilmu

Rauf, M., (2002), Masa Depan Pembangunan Politik Indonesia: Jakarta

Seminar Pemilihan Umum 2002, Pemilihan Umum dan Masalah-Masalah yang ditimbulkan. Jakarta: Dewan Mahasiswa Universitas Indonesia.

Sjamsuddin, N, (2002). Partai Nasional Indonesia dan Politik pada Skripsi Fakultas Ilmu-Ilmu Sosial, Universitas Indonesia: Jakarta.

Suharyanto, A., (2014). Partisipasi Politik Masyarakat Tionghoa dalam Pemilihan Kepala Daerah, Jurnal Ilmu Pemerintahan dan Sosial Politik, 2 (2): 166-175

, (2016), Pengaruh Surat Kabar Sebagai Salah Satu Media Penyampaian Informasi Politik Terhadap Partisipasi Politik Masyarakat, Jurnal Administrasi Publik, 6 (2):182-190

Sukarna, (2003). Sistem Politik, Bandung: PT. Citra Aditya Bakti. 